\title{
In vitro Protein Synthesis and Measurement of the Stability of Messenger RNA in the Blue-green Alga, Anabaena variabilis
}

\author{
By C. K. LEACH* AND N. G. CARR \\ Department of Biochemistry, University of Liverpool, \\ P.O. Box 147, Liverpool L69 $3 B X$ \\ (Received I4 June I973; revised I8 September 1973)
}

\begin{abstract}
SUMMAR Y
A cell-free preparation of the blue-green alga, Anabaena variabilis, that incorporates ${ }^{14} \mathrm{C}$-labelled amino acids into protein has been prepared and characterized. The activation of amino acids to amino acid transfer RNAs was characterized, and assembly of these into peptides has been described with respect to cofactor requirements and antibiotic sensitivity. The properties of these systems and the effect of antibiotics on them are similar to those of bacteria. Both natural and synthetic messenger RNA were effective in peptide formation. The kinetics of incorporation of $\left[{ }^{14} \mathrm{C}\right]$ uracil into RNA has been examined and the stability of labelled RNA from A. variabilis measured by radioactivity loss and by its role in directing peptide synthesis. The half-life of messenger RNA from this organism is approximately I 2 min, and as such is comparable to that of bacteria when based upon the mean generation time of the respective organisms.
\end{abstract}

\section{INTRODUCTION}

Despite increasing knowledge of intermediary metabolism in blue-green algae (see Smith, 1973) little attention has been directed towards understanding the formation of macromolecules by these organisms. The limited studies, both in vivo and in vitro, that have been carried out have underlined the prokaryotic nature of blue-green algae. DNAdependent RNA polymerase has been isolated from Anacystis nidulans and shown to have a subunit composition similar to that of the enzyme from Escherichia coli (Helm \& Zillig, 1967; Herzfeld \& Zillig, 197I). $N$-formyl-methionyl transfer RNA has been implicated in the initiation of peptide chain synthesis in Nostoc sp. (Sala, Sensi \& Parisi, 1970). Known inhibitors of $70 \mathrm{~S}$ ribosome protein synthesis are effective against blue-green algae (see Leach \& Herdman, 1973).

The synthesis of DNA, RNA and protein by intact Anacystis nidulans (Hayashi, Ishida \& Kikuchi, I969) can be regulated by a light/dark regime and the periodic synthesis of macromolecules in a synchronized culture of this organism has been described (Herdman, Faulkner \& Carr, 1970).

This paper describes the synthesis of peptides by a cell-free preparation of Anabaena variabilis studied by using a procedure based upon that of Forchhammer \& Kjeldgaard (1967). The properties of this system are discussed and the effect of antibiotics examined. The stability of messenger RNA in this organism has been determined by direct means and by examining the effect of RNA-synthesis inhibitors on cultures containing ${ }^{14} \mathrm{C}$-labelled RNA. These results are discussed in the light of the apparent lack of control at the transcriptional level in blue-green algae.

* Present address: The Corporate Laboratory, I.C.I. Ltd, Runcorn, Cheshire. 


\section{METHODS}

Non-standard abbreviations. HEPES: $N$-2 hydroxyethylpiperazine- $N^{1}$-2-ethanosulphoric acid. HEMS buffer: Io mM-HEPES, I mM-EDTA, 0.5 M-sorbitol, 6 mM-2-mercaptoethanol, adjusted to $\mathrm{pH} 7 \cdot 4$ with acetic acid. HAMK buffer: Io mM-HEPES, $40 \mathrm{~mm}-\mathrm{KCl}, 40 \mathrm{~mm}$ ammonium acetate, I0 mM-magnesium acetate, $0.5 \mathrm{~mm}-\mathrm{CaCl}_{2}, 0.0 \mathrm{Im}$ m-zinc acetate, 6 mM-2-mercaptoethanol, brought to $\mathrm{pH} 3.4$ with acetic acid. PVS-acetate buffer: Io mMsodium acetate, $50 \mathrm{~mm}-\mathrm{NaCl}, 0 \cdot \mathrm{I}$ mM-magnesium acetate, adjusted to $\mathrm{pH} 5 \cdot \mathrm{I}$ with $\mathrm{HCl}$. Polyvinyl sulphate $(2 \mu \mathrm{g} / \mathrm{ml})$ was added just prior to use. TSM buffer: Io mM-tris, $4 \mathrm{~mm}$ -

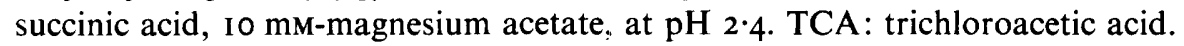

Growth of Anabaena variabilis. The organism was grown photosynthetically on the mineral salt medium C of Kratz \& Myers (1955) as previously described (Carr \& Hallaway, I965) and growth was monitored by measuring the extinction of the culture at $650 \mathrm{~nm}$ in a Unicam SP60o spectrophotometer. Under the condition employed the extinction was proportional to cell dry weight and an extinction of $\mathrm{I} \cdot \mathrm{O}$ at $650 \mathrm{~nm}$ wavelength corresponded to $0.36 \mathrm{~g}$ dry wt of organism/l of culture.

Preparation of extracts for cell-free protein synthesis. Anabaena variabilis was grown to a dry weight of 0.3 to $0.4 \mathrm{mg} / \mathrm{ml}$ and then the entire culture poured on to crushed ice and harvested at $4{ }^{\circ} \mathrm{C}$. The pellet was washed three times with $0.02 \mathrm{M}$-HEPES-HCl buffer $(\mathrm{pH} \mathrm{7} 4$ ) and resuspended in HEMS buffer (200 to $300 \mathrm{mg}$ dry wt organisms $/ \mathrm{ml}$ ). Lysozyme $(2 \mathrm{mg} / \mathrm{ml}$ ) was added and the suspension incubated at $34{ }^{\circ} \mathrm{C}$ for $30 \mathrm{~min}$ and then centrifuged $(3000 \mathrm{~g})$ for $20 \mathrm{~min}$ at $4{ }^{\circ} \mathrm{C}$. The pellet was washed once with HEMS buffer and resuspended in HAMK buffer (200 to $300 \mathrm{mg}$ dry wt of organism $/ \mathrm{ml}$ ). DNase which was free of RNaseactivity was added $(20 \mu \mathrm{g} / \mathrm{ml})$ and the organisms disintegrated in a French pressure cell at ${ }^{\circ}{ }^{\circ} \mathrm{C}$ and a pressure of $8000 \mathrm{lb} / \mathrm{in}^{2}$. The broken suspension was then incubated at $34{ }^{\circ} \mathrm{C}$ for $30 \mathrm{~min}$. This incubation reduced the high basal amino acid incorporation due to endogenous messenger RNA and thus increased the response of the system to the addition of mRNA. The broken suspension was then centrifuged at $30000 \mathrm{~g}$ for $30 \mathrm{~min}$ and the supernatant aspirated and dialysed overnight against the HAMK buffer. Extracts were used immediately since storage at $-\mathrm{I} 5$ or $-70^{\circ} \mathrm{C}$ led to a loss of peptide-forming ability.

Preparation of aminoacyl $t R N A$ synthetases. The crude 'extract' described above was further fractionated by an additional centrifugation at I00000 $\mathrm{g}$ for $3 \mathrm{~h}$. The upper $60 \%$ of the supernatant was collected and assayed for aminoacyl tRNA synthetases activities.

Methylated albumin kieselguhr column chromatography of nucleic acids. Methylated albumin kieselguhr (MAK) column chromatography of nucleic acids was carried out as described by Mandell \& Hershey (1960).

Assay of aminoacyl $t R N A$ synthetases and aminoacyl $t R N A$. The standard incubation mixture for the assay of the aminoacyl tRNA synthetases contained: $30 \mu \mathrm{l}$ of a prepared solution of amino acids, ATP, and ATP generating system and salts; $30 \mu$ l enzyme extract; and $40 \mu \mathrm{l}$ of tRNA solution in HAMK buffer. The concentrations of each component employed are given in Table $\mathrm{I}$. The reaction mixtures were composed at $\mathrm{o}^{\circ} \mathrm{C}$ and the reaction initiated by placing in a water bath at $34{ }^{\circ} \mathrm{C}$. After incubation for the required time, the tubes were again placed in ice and $0.5 \mathrm{ml}$ of cold $10 \%$ trichloroacetic acid was added. The precipitated RNA was centrifuged down, washed twice with $\mathrm{I} \mathrm{ml} 5 \%$ trichloroacetic acid, and the final pellet incubated at $34{ }^{\circ} \mathrm{C}$ in $0.2 \mathrm{ml}$ of $\mathrm{I} \mathrm{M}-\mathrm{NaOH}$ for $30 \mathrm{~min}$, which resulted in a solution of tRNA. The tubes were recentrifuged and $0.1 \mathrm{ml}$ of the supernatant was collected, dried on a planchet and counted for radioactivity in a Nuclear Chicago Automatic gas flow counter. 
Table I. Composition of aminoacyl-tRNA forming system

\begin{tabular}{|c|c|c|}
\hline Volume & Components & Concentration \\
\hline $30 \mu l$ & $\begin{array}{l}\text { Stock solution containing: } \\
\text { HEPES } \\
\mathrm{KHCO}_{3} \\
\text { Acetic acid } \\
\text { ATP } \\
\text { Creatine phosphate } \\
\text { Creatine phosphokinase } \\
\text { I9 L-Amino acids } \\
\text { I L-Amino acid* }\end{array}$ & $\begin{array}{c}150 \mathrm{~mm} \\
100 \mathrm{mM} \\
84 \mathrm{mM} \\
84 \mathrm{mM} \\
16.8 \mathrm{mM} \\
100 \mathrm{mg} / \mathrm{ml} \\
\text { (Each) } 15.0 \mathrm{~mm} \\
15.0 \mathrm{~mm}\end{array}$ \\
\hline $40 \mu 1$ & tRNA in HAMK buffer & $3 \mathrm{mg} / \mathrm{ml}$ \\
\hline $30 \mu 1$ & High-speed supernatant enzyme & $\begin{array}{l}10-30 \mathrm{mg} \\
\text { protein } / \mathrm{ml}\end{array}$ \\
\hline
\end{tabular}

${ }^{14} \mathrm{C}$-labelled aminoacyl tRNAs were prepared from a scaled-up version of the above incubation mixture. After incubation, the protein was extracted with phenol-cresol mixture as described for the preparation of tRNA.

Preparation of $t R N A$ from Anabaena variabilis. Harvested organisms were washed with 0.0 I M-acetate buffer ( $\mathrm{pH}_{5} .0$ ) containing $0.0 \mathrm{I} \mathrm{M}-\mathrm{MgCl}_{2}$ and $0.01 \mathrm{mM}^{-} \mathrm{ZnCl}_{2}$. After resuspension in the same buffer $(200 \mathrm{mg}$ dry $\mathrm{wt} / \mathrm{ml})$, the organisms were extruded through a French pressure cell at $0.4{ }^{\circ} \mathrm{C}$ at a pressure of 18000 to $20000 \mathrm{lb} / \mathrm{in}^{2}$. DNase $(5 \mu \mathrm{g} / \mathrm{ml})$ was added and the broken-cell suspension was incubated at $34{ }^{\circ} \mathrm{C}$ for $30 \mathrm{~min}$. An equal volume of phenol-cresol mixture (prepared by the addition of $140 \mathrm{ml}$ of freshly distilled $m$-cresol, $\mathrm{I} I 0 \mathrm{ml}$ of acetate buffer and I $\mathrm{g}$ of 8-hydroxy-quinoline to I $\mathrm{kg}$ phenol) was added to the broken-cell suspension and the two phases were rapidly mixed for $30 \mathrm{~min}$. The resulting emulsion was separated by centrifugation at $10000 \mathrm{~g}$ for $20 \mathrm{~min}$ at $2{ }^{\circ} \mathrm{C}$, the upper aqueous phase being removed by a Pasteur pipette. The phenol-cresol extraction was repeated twice. One drop of $2 \mathrm{M}-\mathrm{NaCl}$ was added to the final aqueous phase and the RNA precipitated by the addition of 2 vol. of cold ethanol and cooling to $-10{ }^{\circ} \mathrm{C}$ for at least $30 \mathrm{~min}$. The precipitate was collected by centrifugation and then homogenized with $20 \mathrm{ml}$ of ice-cold $2 \mathrm{M}-\mathrm{NaCl}$. Care was taken to ensure that the temperature remained at o to I ${ }^{\circ} \mathrm{C}$. The resultant suspension was centrifuged at $10000 \mathrm{~g}$ for $20 \mathrm{~min}$, the supernatant collected and the tRNA precipitated by the addition of ethanol. The precipitated tRNA was washed once with aqueous ethanol $(30 \%, \mathrm{v} / \mathrm{v})$ and re-dissolved in HAMK buffer at the required concentration $(3 \mathrm{mg} / \mathrm{ml})$. Sucrose density-gradient analysis and polyacrylamide-gel electrophoresis indicated that at least $95 \%$ of the RNA isolated by this procedure behaved as 4 S RNA.

Preparation of total $R N A$ for the assay of $m R N A$ content. A suitable quantity of organism (200 to $500 \mathrm{mg}$ dry wt) was poured on to crushed frozen medium, harvested, and resuspended at 0 to $2{ }^{\circ} \mathrm{C}$ in 2 to $4 \mathrm{ml}$ of PVS-acetate buffer. Cells were disrupted by ultrasonic treatment in an MSE $60 \mathrm{~W}, 20 \mathrm{kHz}$ sonic disintegrator for two periods of $45 \mathrm{~s}$ at maximum output. Sodium dodecyl sulphate $(0.2 \mathrm{ml}, \mathrm{I} 2 \% \mathrm{w} / \mathrm{v})$ was added and the suspension deproteinized as described for the preparation of tRNA. The total RNA was precipitated with ethanol as described above and the recovered RNA was redissolved in PVS-acetate buffer and the ethanol precipitation repeated twice more. The final precipitate was redissolved in TSM buffer, treated with DNase $(5 \mu \mathrm{g} / \mathrm{ml})$ at $34{ }^{\circ} \mathrm{C}$ for $20 \mathrm{~min}$, re-extracted twice with phenolcresol mixture and the RNA precipitated twice with ethanol. The final precipitate was dissolved in HAMK buffer to a concentration of about $5 \mathrm{mg} / \mathrm{ml}$ and stored at $-15{ }^{\circ} \mathrm{C}$. 
Table 2. Composition of cell-free system for protein synthesis

$\begin{gathered}\text { Volume used } \\ (\mu 1)^{*} \\ 0-80 \\ 30 \\ 10 \\ 60\end{gathered}$

Component
Total cellular RNA dissolved in HAMK buffer
Cell-free extract in HAMK buffer
tRNA from Anabaena variabilis in HAMK buffer
Stock solution containing:
HEPES
KHCO
Acetic acid
ATP
GTP
Creatine phosphate
Creatine phosphokinase
I9 L-Amino acids
I L-Amino acid $\left({ }^{14} \mathrm{C}-\right.$ labelled, $\left.5-34 \mu \mathrm{Ci} / \mu \mathrm{mol}\right)$

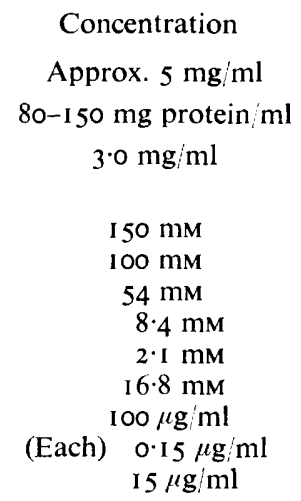

* Plus in all cases, HAMK buffer to adjust the final volume to $200 \mu 1$.

Incorporation of amino acids into peptides by extracts of Anabaena variabilis. The assay was carried out in a $200 \mu \mathrm{l}$ vol. by mixing $60 \mu \mathrm{l}$ of a stock solution of salts, triphosphate and amino acids, 0 to $80 \mu \mathrm{l}$ of total cellular RNA dissolved in HAMK buffer, $30 \mu \mathrm{l}$ of enzyme preparation and $10 \mu \mathrm{l}$ of tRNA. The volume was adjusted to $200 \mu \mathrm{l}$ with HAMK buffer (see Table 2). Forchhammer \& Kjeldgaard's (1967) precaution of removing sodium ions from the stock solution was observed.

After mixing the assay solutions at $0{ }^{\circ} \mathrm{C}$, the tubes were covered with 'Parafilm' and the reaction started by placing them in a water bath at $34{ }^{\circ} \mathrm{C}$ for a preset interval. After incubation, the reaction mixture was diluted with $400 \mu \mathrm{l}$ of HAMK buffer and the reaction stopped by the addition of $600 \mu \mathrm{l}$ of $\mathrm{NaOH}$. The tubes were further incubated for $30 \mathrm{~min}$ at $34{ }^{\circ} \mathrm{C}$ to allow the release of amino acids from the aminoacyl-tRNA. After cooling to room temperature, trichloroacetic acid $(0.2 \mathrm{ml}, 10 \%, \mathrm{w} / \mathrm{v})$ containing $\mathrm{I} \mathrm{mg} / \mathrm{ml}$ of the amino acid used as label in the experiment was added. The mixture was left for at least $2 \mathrm{~h}$ at 0 to $4{ }^{\circ} \mathrm{C}$ to allow for complete precipitation. The precipitates were collected on cellulose-nitrate filters (Millipore), washed six times with $4 \mathrm{ml}$ of $5 \%$ trichloroacetic acid at o to $4{ }^{\circ} \mathrm{C}$, and the filters were attached to planchets, dried and counted. In experiments where inhibitors were used these were added in a small volume of HAMK buffer to the standard reaction mixture.

Chenicals. ATP, creatine phosphate, creatine phosphokinase and polyuradylic acid were purchased from C. F. Boehringer, Mannheim, Germany. Rifampicin and puromycin were from Sigma (London) Chemical Co., London S.W.6, and cycloheximide from Koch Light Ltd, Colnbrook, Buckinghamshire. Lincomycin was a gift from Upjohn Ltd. Radioactive chemicals were from the Radiochemical Centre, Amersham, Buckinghamshire. All other chemicals were from B.D.H., Poole, Dorset.

\section{RESULTS}

\section{Measurement of RNA stability in whole cells by use of inhibitors}

The rate of loss of radioactivity from the in vivo RNA fraction after inhibition of further RNA synthesis by a transcription inhibitor may be used to measure the stability of RNA in an organism (Gros et al. I96I ; Levinthal, Keynan \& Higa, 1962). Initial attempts to inhibit 


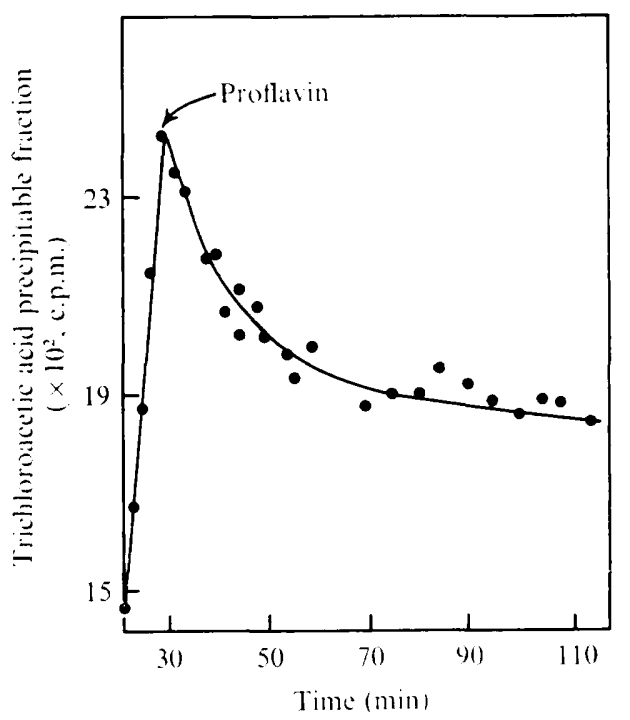

Fig. I

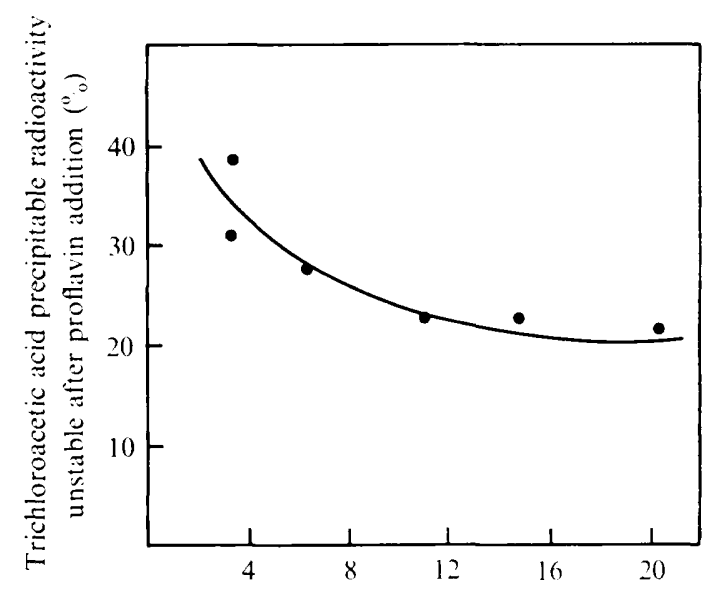

Preincubation time (" of mean generation time)

Fig. 2

Fig. I. The incorporation of $\left[2-{ }^{1+} \mathrm{C}\right]$ uracil into a trichloroacetic acid precipitable fraction by Anabaena variabilis. Radioisotope $(5 \mu \mathrm{Ci}$, specific radioactivity $55 \mathrm{mCi} / \mathrm{mm})$ was added to $\mathrm{I} l$ of growing culture $30 \mathrm{~min}$ before the addition of proflavin $(5 \mu \mathrm{g} / \mathrm{ml})$ and the incorporation into trichloroacetic acid precipitable fraction was followed. At least $95 \%$ of this radioactivity was soluble in hot trichloroacetic acid and alkali and was attributed to RNA.

Fig. 2. Unstable RNA in relation to the ${ }^{16} \mathrm{C}$ labelling period before the addition of proflavin. Organisms were incubated with $\left[2-{ }^{14} \mathrm{C}\right]$ uracil $(5 \mu \mathrm{Ci} / 1$, specific radioactivity $0.5 \mu \mathrm{Ci} / \mathrm{mm})$ for various times before the addition of proflavin $(5 \mu \mathrm{g} / \mathrm{ml})$. The amount of radioisotope in RNA was as in Fig. I.

RNA synthesis in Anabaena variabilis by actinomycin D or rifampicin were unsuccessful. Both prevented the uptake of $\left[2{ }^{1+} \mathrm{C}\right]$ uracil for a short period of time, but the inhibition was soon overcome, possibly because these compounds were light-sensitive. Even with rifampicin at high concentration (up to $2 \mathrm{mg} / \mathrm{ml}$ ), A. variabilis soon recovered the ability to assimilate $\left[2-{ }^{14} \mathrm{C}\right]$ uracil. However, RNA synthesis in this organism was blocked by low $(5 \mu \mathrm{g} / \mathrm{ml})$ concentrations of proflavin which has been previously reported to inhibit RNA synthesis (Gros et al. 196I). There was no further increase in the radioactivity in the trichloroacetic acid precipitable fraction after proflavin addition and an exponential decay of radioactivity in this fraction was observed (Fig. I). This decay presumably reflected the breakdown of unstable RNA (i.e. messenger RNA, nascent ribosomal RNA and nascent transfer RNA). The half-life of this fraction was determined as Io to $12 \mathrm{~min}$ in cultures of $A$. variabilis growing at a mean generation time of $5 \mathrm{~h}$ at $34^{\circ} \mathrm{C}$. When the growth rate of $A$. variabilis was altered by adjustment of illumination, the unstable RNA was degraded more slowly in slower growing cultures; at a mean generation time of $24 \mathrm{~h}$ the half-life of unstable RNA was $26 \mathrm{~min}$. A similar correspondence between half-life of messenger RNA and growth rate of culture has been observed in Escherichia coli by Gray \& Midgley (1970). The amount of the trichloroacetic acid precipitable radioactivity that was unstable depended upon the period of incubation with $\left[2{ }^{14} \mathrm{C}\right]$ uracil before the addition of proflavin (Fig. 2). Growth on media containing $\left[2{ }^{14} \mathrm{C}\right]$ uracil for 6 to 7 generations before the addition of proflavin showed that $17.5 \pm 1 \cdot 2 \%$ (mean of five determinations) of the radioactivity was lost from the trichloroacetic acid precipitable fraction by the addition of proflavin. MAK column 


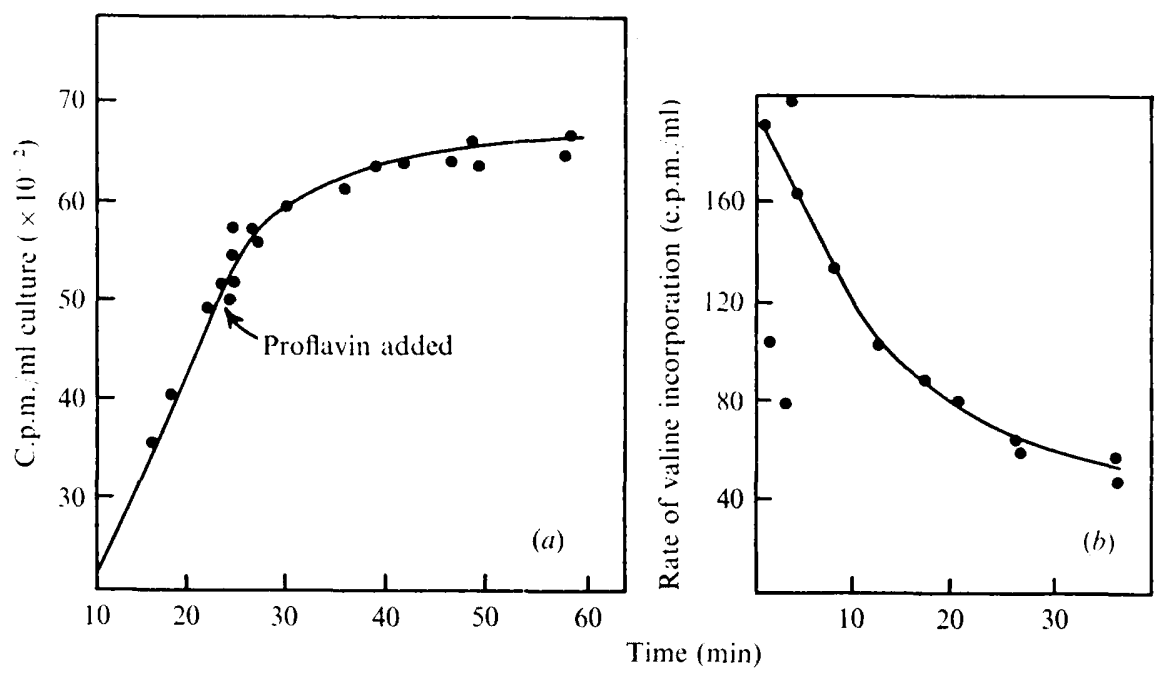

Fig. 3. (a) Incorporation of $\left[\mathrm{U}-{ }^{14} \mathrm{C}\right]$ valine ( $5 \mu \mathrm{Ci} / 1$, specific radioactivity $2.5 \mu \mathrm{Ci} / \mu \mathrm{M}$ ) into a trichloroacetic acid precipitable fraction of Anabaena variabilis before and after the addition of proflavin $(5 \mu \mathrm{g} / \mathrm{ml})$. (b) Rate of $\left[\mathrm{U}-{ }^{14} \mathrm{C}\right]$ valine incorporation after addition of proflavin. Rate was calculated as $\left(N_{t}-N_{0}\right) / t$, where $N_{0}=$ TCA-precipitable radioactivity at point of addition of proflavin, $t=$ time $(\mathrm{min})$ after proflavin addition, and $N_{t}=$ TCA-precipitable radioactivity at time $t$.

analysis of the RNA isolated from cells grown in $\left[2-{ }^{14} \mathrm{C}\right]$ uracil showed all the RNA species to be labelled at the same specific activity (expressed as c.p.m./ $E_{260}$ unit) and it was concluded, therefore, that $17.5 \%$ of the total cellular RNA of $A$. variabilis was unstable after the addition of proflavin. These observations are in contrast to the lower values of unstable RNA which have been reported in bacteria (Gros et al. 1961).

The incorporation of $\left[\mathrm{U}-{ }^{14} \mathrm{C}\right]$ valine into a trichloroacetic acid precipitable fraction by Anabaena variabilis under similar conditions, was investigated and found to be inhibited, although not immediately so, by the addition of proflavin (Fig. 3a). Since incorporation of $\left[\mathrm{U}-{ }^{14} \mathrm{C}\right]$ valine into the trichloroacetic acid precipitate was taken as a measure of protein synthesis, by plotting the rate of $\left[\mathrm{U}_{-}{ }^{14} \mathrm{C}\right]$ valine incorporation in the presence of proflavin against time, the rate of decay of protein synthesizing ability, presumably as a result of mRNA breakdown, could be determined (Fig. $3 b$ ). The half-life of protein-synthesizing ability after the addition of proflavin was determined as 12 min in cultures growing with a mean generation time of 5 to $6 \mathrm{~h}$ but this half-life was increased to 18 to $20 \mathrm{~min}$ in cultures which had been grown with a mean generation time of 20 to $24 \mathrm{~h}$.

\section{Amino acid activation by extracts of Anabaena variabilis}

The activation of amino acids to form aminoacyl-tRNA by extracts of Anabaena variabilis was demonstrated by the procedure described (Fig. 4). Separate preparations of the enzymes exhibited specific activities of amino acid activating activities which differed by as much as a factor of four when measured by the radioactivity converted from amino acid to aminoacyl-tRNA. Despite this variability, consistent patterns were obtained between experiments. Thus, in each case, the conversion required ATP and an energy-generating system and the activation was dependent upon the addition of enzyme. The reduced level of incorporation observed when RNA was omitted from the incubation mixture indicated that the enzyme extracts used contained only low levels of RNA. Replacement of HEPES buffer by tris buffer in the preparation of the enzymes, and in the enzyme incubation 


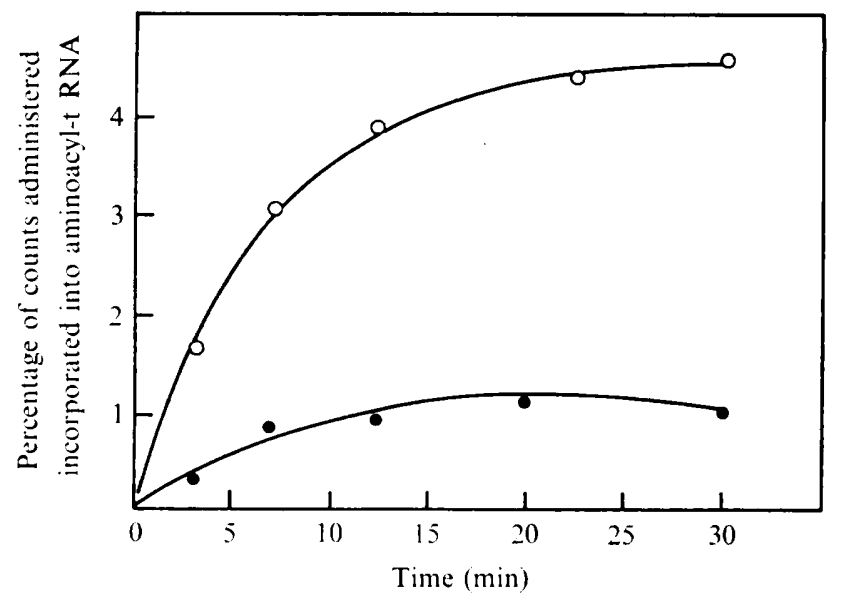

Fig. 4. Incorporation of amino acids into aminoacyl-tRNA fraction by preparation of Anabaena variabilis. Incubation conditions were as described in Methods, each reaction mixture contained I $50 \mu \mathrm{g}$ RNA. $\bigcirc$, Complete; 0 , without added tRNA.

mixture, did not greatly affect the amount of amino acid activated. Assuming each transferRNA species is present in equimolar proportions, 80 to $90 \%$ loading of RNA with amino acids could be achieved.

\section{Incorporation of amino acids into peptides by cell-free preparation of Anabaena variabilis}

Studies on the kinetics of amino acid incorporation into a trichloroacetic acid precipitable fraction, as described in Methods with $83 \mu \mathrm{g}$ RNA as a source of messenger, showed a plateau of incorporation after $40 \mathrm{~min}$; an incubation time of $45 \mathrm{~min}$ was chosen for the standard assay period. All peptide-forming systems isolated from exponentially growing cultures of Anabaena variabilis showed a high basal level amino-acid incorporation indicating the presence of contaminating messenger RNA. This could be reduced by incubation of the broken-cell suspension at $38{ }^{\circ} \mathrm{C}$ for $80 \mathrm{~min}$. The absolute level of amino acid incorporation differed with separate enzyme preparations, although the pattern of cofactor dependence and response to the addition of RNA was found to be constant between experiments. $\mathrm{Mg}^{++}$ion concentration affected the degree of amino acid incorporation markedly and maximal activity was obtained at concentrations around $5 \mathrm{~mm}$. The dependence of amino acid incorporation on the addition of tRNA, prepared from A. variabilis as described, indicates that the tRNA in extracts was insufficient to allow maximal peptide synthesis (Fig. 5). Thus the addition of exogenous tRNA increased the rate-limiting step (the activation of amino acids to aminoacyl-tRNAs). The addition of tRNA in excess of $80 \mu \mathrm{g}$, however, reduced the amount of peptide formed, presumably either by the tRNA inhibiting the process itself or, possibly, another component in the tRNA preparation inhibiting peptide synthesis.

Omission of ATP, GTP or the ATP-generating system reduced the level of amino acid incorporation and the inclusion of $\mathrm{RNase}$ and $\mathrm{Na}^{+}$ions was markedly inhibitory (Table 3). When HEPES buffer was replaced by tris buffer in the salts, triphosphate and amino acids solution, there was a reduction in activity, whilst replacement of HEPES buffer by tris buffer in the preparation of the extracts resulted in almost inactive preparations (Table 3). 


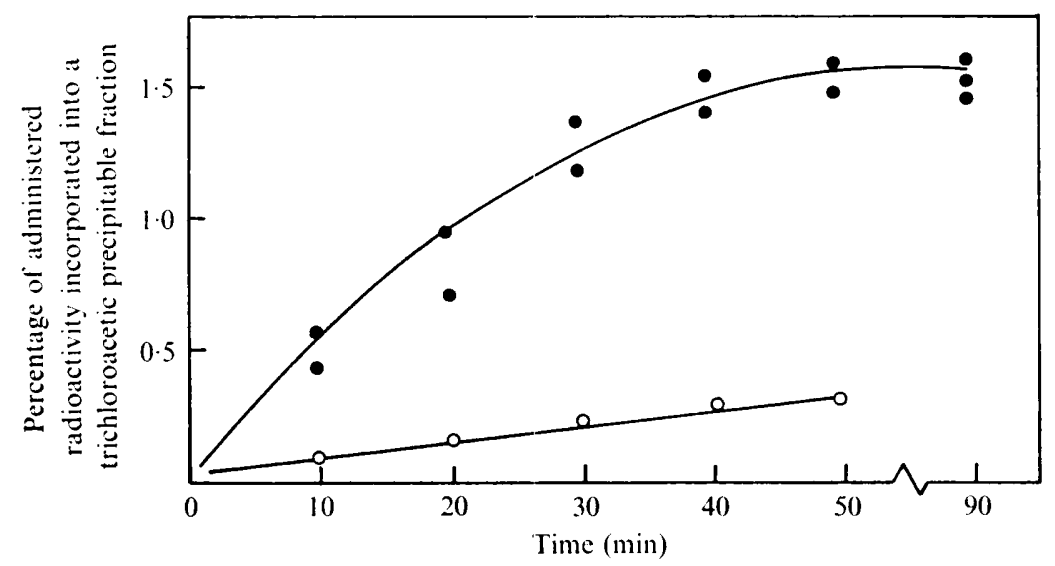

Fig. 5. Dependence of peptide synthesis upon the addition of tRNA, for the preparation from Anabaena variabilis. Except for the amounts of tRNA added, incubation conditions were as in Methods. Complete; $\bigcirc$, without added RNA.

Table 3. Cofactor dependence and properties of incorporation of amino acids into peptides by the cell-free system from Anabaena variabilis

Reaction mixture

Complete

- ATP and ATP generating system

- GTP

- ATP generating system

- Enzyme preparation

+ RNase $(5 \mu \mathrm{g})$

$+\mathrm{NaCl}(0.1 \mathrm{~mm})$

HEPES in the stock solution replaced by tris

Enzyme prepared in buffer in which HEPES was replaced by tris buffer

$$
\begin{gathered}
\text { Activity (\%) } \\
100 \\
10-12 \\
12-25 \\
20-30 \\
0 \\
12-15 \\
15-27 \\
84-96 \\
5-20
\end{gathered}
$$

Table 4. Inhibition by antibiotics of peptide biosynthesis and amino acid activation by extracts of Anabaena variabilis

Antibiotic

None

Rifampicin

Chloramphenicol

Erythromycin

Puromycin

$$
\underset{(\mu \mathrm{g})}{\text { Quantity }}
$$$$
\begin{array}{r}
- \\
1 \\
5 \\
10 \\
1 \\
5 \\
20
\end{array}
$$$$
2
$$$$
5
$$

0.5

2
Activity remaining $(\%)$

Peptide biosynthesis Amino acid activation

$\begin{array}{rr}100 & 100 \\ 105 & 96 \\ 103 & 98 \\ 100 & 92 \\ 78 & 87 \\ 25 & 92 \\ 10 & 88 \\ 70 & 91 \\ 40 & 85 \\ 3 & 73 \\ 60 & 93 \\ 23 & 104\end{array}$




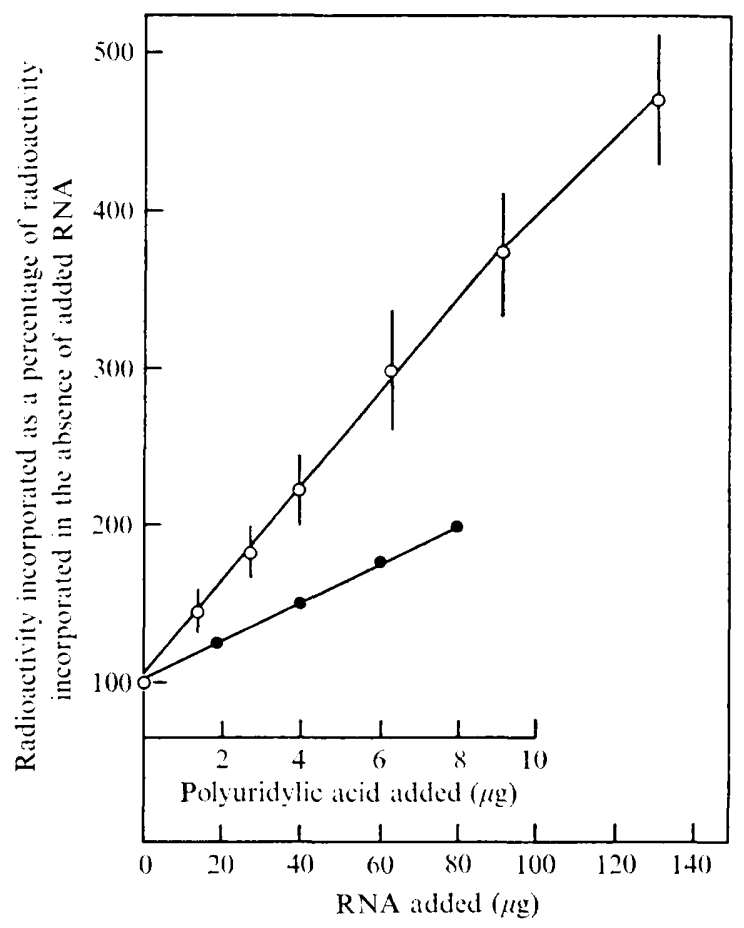

Fig. 6. Response of cell-free protein-synthesizing system from Anabaena variabilis to added RNA. Assays were as described in Methods. $\mathrm{O}$, Natural RNA extracted from Anabaena variabilis; $\mathbf{0}$, polyuridylic acid as a source of non-natural messenger. The vertical bars indicate the range of activity obtained from four different batches of RNA prepared separately from the same culture of $A$. variabilis. The cell-free protein-forming system was the same in each case.

The inhibition by several antibiotics of peptide biosynthesis by extracts of Anabaena variabilis was tested (Table 4). The potent inhibitor of RNA polymerase, rifampicin, had little effect on protein synthesis indicating that peptide synthesis by extracts was not dependent upon RNA biosynthesis. Lincomycin, erythromycin, chloramphenicol and puromycin were effective inhibitors of peptide biosynthesis by the extracts, but were without effect on the activation of amino acids. Thus these inhibitors acted at a stage after amino acid activation and before peptide-bond formation, probably by acting at the ribosome level. Actidione (cycloheximide), a known inhibitor of $80 \mathrm{~S}$ ribosomes, had little effect on peptide biosynthesis by extracts of $A$. variabilis, although a small degree of inhibition was detected at high levels of the drug.

Response of the cell-free protein synthesizing system to the addition of $m R N A$

The amount of amino acid incorporation carried out by extracts of Anabaena variabilis was raised by the addition of total RNA prepared from the organism (Fig. 6). The response was linear with respect to added RNA and different batches of RNA prepared gave reproducible stimulation of amino acid incorporation. The absolute rate of amino acid incorporation varied significantly between different enzyme preparations and in comparing the mRNA content of different RNA preparations, the same protein-biosynthetic system was used. The response to polyuridylic acid when using $\left[{ }^{14} \mathrm{C}\right]$ phenylalanine was low, indicating that the synthetic polynucleotide was not as good a source of messenger activity 


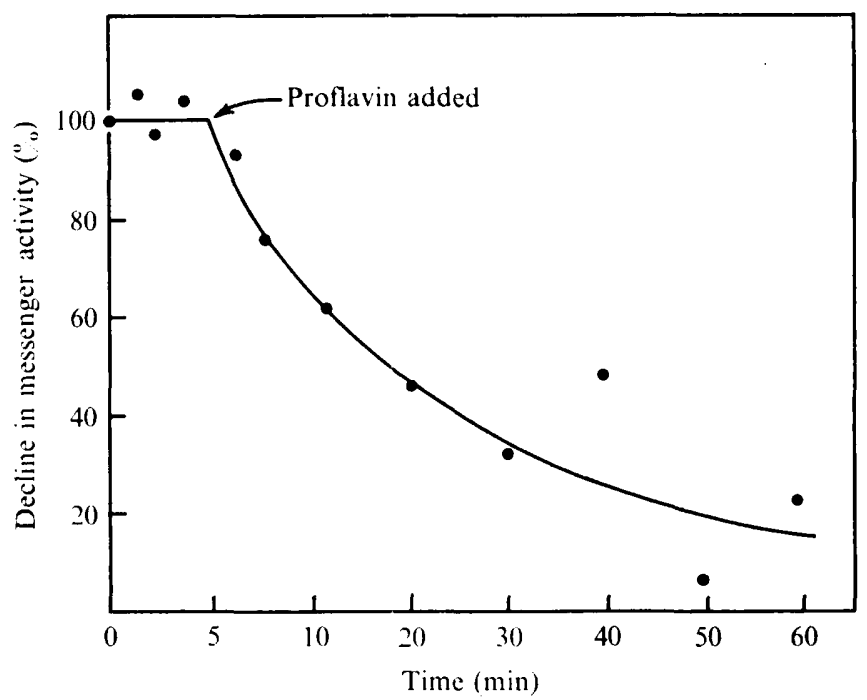

Fig. 7. The loss of messenger activity of RNA isolated from Anabaena variabilis after addition of proflavin $(5 \mu \mathrm{g} / \mathrm{ml})$. RNA samples were isolated and assayed in the protein-synthesizing system as described in Methods.

as natural RNA. Assuming equimolar incorporation of amino acids with natural mRNA, then the natural RNA was at least 20-fold more effective as a source of messenger activity than polyuridylic acid.

\section{Messenger activity of RNA isolated from Anabaena variabilis after the addition of proflavin}

Total cellular RNA was isolated from exponentially growing Anabaena variabilis and from organisms after the addition of proflavin $(5 \mu \mathrm{g} / \mathrm{ml})$. The messenger activity of these RNA samples, measured as the amount of $\left[{ }^{14} \mathrm{C}\right]$ amino acid incorporated/ $\mu \mathrm{g}$ RNA added, was determined in the cell-free protein synthesizing system as described above. The stimulating activity of RNA samples isolated before the addition of proflavin was approximately constant, but the ability of RNA samples isolated after proflavin treatment to support protein synthesis steadily declined (Fig. 7). The loss of ability to support synthesis, presumably a measure of mRNA, had a half-life of 12 to $15 \mathrm{~min}$, a value similar to the half-life of unstable RNA measured as above.

\section{DISCUSSION}

Two approaches may be utilized to measure the stability of messenger RNA: employment of DNA: RNA hybridization after a pulse-labelling of the latter (Pigott \& Midgley, 1968), or use of one of the various inhibitors of RNA polymerase. The former is in principle the procedure of choice since measurements are made on organisms in a steady state of growth. Unfortunately the incorporation rate of nucleotides or nucleosides in Anabaena variabilis was very slow and led to insufficient radioactivity in RNA after pulse-labelling for accurate measurement. This low rate of nucleic-acid precursor incorporation has been described in detail with another blue-green alga, Anacystis nidulans (Pigott \& Carr, 197I). Attention was therefore directed to the application of inhibition of RNA polymerase after uniform labelling of all RNA species by radioactive uracil over several generations. The 
decay of radioactivity-associated RNA following proflavin treatment, by analogy with bacterial systems, represents the decay of messenger and nascent RNA. The half-life of this unstable fraction was approximately $10 \mathrm{~min}$, i.e. $3 \%$ of the generation time and comparable with that in Escherichia coli. The higher total proportion $(17.5 \%)$ of unstable RNA in $A$. variabilis than $E$. coli cannot at this stage be explained. The cell-free protein synthesizing system reconstituted from disintegrated $A$. variabilis had basically the same characteristics as that of $E$. coli as described by Forchhammer \& Kjeldgaard (1967). This reflects the similarity between the physical properties of DNA and ribosomal RNA of bacteria and bluegreen algae (see Whitton, Carr \& Craig, I97I ; Leach \& Herdman, 1973), and is a result that would perhaps be expected from their common prokaryotic structure. The absolute level of amino acid incorporation into peptides by the complete system varied with different preparations, indicating that at least one component was sensitive to a stage of isolation. The pattern of cofactor dependence was, however, consistent between experiments. The effects of antibiotics are consistent with their effects on growing cultures of blue-green algae. The peptide-synthesizing systems isolated from $A$. variabilis did differ from those of bacteria in that very low activity was obtained after preparation in tris buffer. It had previously been observed that tris, but not phosphate, buffer led to a loss of a protein fragment from the $50 \mathrm{~S}$ component of $70 \mathrm{~S}$ ribosomes from A. variabilis (Craig \& Carr, 1968). It may be that the failure to produce a functional protein-synthesizing system in tris buffer is a consequence of the relative lack of stability of $70 \mathrm{~S}$ ribosomes from $A$. variabilis in this buffer.

Total RNA extracted from growing cells could serve as a suitable source of messenger activity to direct peptide synthesis in the cell-free system described. The loss of this ability by RNA extracted from proflavin-treated cultures indicated that proflavin resulted in a loss of messenger RNA content. The stability of the messenger fraction, measured by the ability to support peptide synthesis, gave a half-life of the same order of magnitude (I 2 to I $5 \mathrm{~min}$ ) as the half-life of the unstable RNA (IO $\mathrm{min}$ ) discussed above. The results described lead us to conclude that the bulk of messenger RNA from Anabaena variabilis is unstable and has a half-life comparable with that found in heterotrophic bacteria. These results do not rule out the possibility of a small, stable messenger RNA pool.

Considerable enzymic evidence has led to the suggestion (Carr, Hood \& Pearce, 1969; Carr, 1973) that obligately phototrophic blue-green algae are unable to repress enzyme synthesis and that this lack of control over specific RNA synthesis is the characteristic feature of obligate autotrophic physiology. It has been postulated that a possible corollary of this would be that they may not possess unstable messenger RNA, which is a necessary prerequisite of transcriptional control (Carr, Hood \& Leach, 1972). The results presented indicate that this suggestion is not applicable to the messenger RNA of Anabaena variabilis, which shows instability of the same order as in other prokaryotic organisms.

We are indebted to the Science Research Council and the Medical Research Council for their support and to Dr G. H. Pigott for valuable discussions. 


\section{REFERENCES}

CARr, N. G. (1973). Metabolic control and autotrophic physiology. In The Biology of Blue-Green Algae, pp. 39-65. Edited by N. G. Carr and B. A. Whitton. Oxford: Blackwells Scientific Publications.

CARR, N. G. \& Hallaway, M. (I965). Reduction of phenol-2,6-dichlorophenol in dark and light by the blue-green alga, Anabaena variabilis. Journal of General Microbiology 39, 335-344.

CARR, N. G., HoOD, W. \& LeACH, C. K. (1972). A new approach to the mechanism of the obligately autotrophic physiology of Anabaena variabilis. In Taxonomy and Biology of Blue-Green Algae, pp. 494-500. Edited by T. V. Desikachary. Madras: University of Madras.

Carr, N. G., Hood, W. \& Pearce, J. (I969). Control and intermediary metabolism in blue-green algae. In Progress in Photosynthetic Research, vol. 3, pp. I565-1569. Edited by H. Metzner. Tübingen: University of Tübingen.

Craig, I. W. \& CARr, N. G. (1968). Ribosomes from the blue-green alga, Anabaena variabilis. Archiv fiir Mikrobiologie 62, 167-177.

ForchHAmmer, J. \& KJeldgaARd, N. O. (1967). Decay of messenger RNA in vivo in a mutant of Escherichia coli 15. Journal of Molecular Biologv 24, 459-469.

Gray, W. J. H. \& Midgley, J. E. M. (1970). The control of ribonucleic acid synthesis in bacteria. Steady state content of messenger ribonucleic acid in Escherichia coli MrE600. Biochemical Journal 120, 279-288.

Gros, F., Gilbert, W., Hiatt, H. H., Attardi, G., Spahr, P. F. \& Warson, J. D. (I96I). Molecular and biological characterization of messenger RNA. Cold Spring Harbor Symposium on Quantitative Biology 26, 1 I I-132.

HayASHI, F., Ishida, M. R. \& KiKUCHI, T. (1969). Macromolecular synthesis in a blue-green alga, Anacystis nidulans, in dark and light phases. Annual Reports of the Research Reactor Institute, Kyoto University 2, 56-66.

HeLM, K. V. D. \& ZiLlig, W. (1967). Reinigung und Eigenschaften der DNA-abhängigen RNA-Polymerase aus Anacystis nidulans. Hoppe-Seyler's Zeitschrift für physiologische Chemie 348, 902-91 2.

Herdman, M., FaulKner, B. M. \& CarR, N. G. (1970). Synchronous growth and genome replication in the blue-green alga Anacystis nidulans. Archiv fiir Mikrobiologie 73, 238-249.

HeRZFELD, F. \& ZILLIG, W. (197I). Subunit composition of DNA-dependent RNA-polymerase of Anacystis nidulans. European Journal of Biochemistry 24, 242-248.

Kratz, W. A. \& Myers, J. (1955). Nutrition and growth of several blue-green algae. American Journal of Botany 42, 282-287.

Leach, C. K. \& Herdman, M. (1973). Structure and function of nucleic acids. In The Biology of Blue-Green Algae, pp. I86-200. Edited by N. G. Carr and B. A. Whitton. Oxford: Blackwells Scientific Publications.

Levinthal, C., Keynan, A. \& Higa, A. (i96:). Messenger RNA turnover and protein synthesis in $B$. subtilis inhibited by actinomycin D. Proceedings of the National Academy of Sciences of the United States of America 48, I63I-39.

Mandell, J. D. \& Hershey, A. D. (1960). A fractionating column for analysis of nucleic acids. Analytical Biochemistry I, 66-77.

Pigott, G. H. \& CARR, N. G. (197I). The assinilation of nucleic acid precursors by intact cells and protoplasts of the blue-green alga Anacystis niduians. Archiv fïr Mikrobiologie 79, I-6.

Pigott, G. H. \& Midgley, J. E. M. (I968). Characterization of rapidly labelled ribonucleic acid hybridization. Biochemical Journal nno, 25I-263.

Sala, F., Sensi, S. \& Parisi, B. (1970). Peptide chain initiation in a species of Nostoc and in chloroplasts of Euglena gracilis. FEBS Letters ro, 89-9I.

Sмгтн, A. J. (1973). Synthesis of metabolic intermediates. In The Biology of Blue-green Algae, pp. I-38. Edited by N. G. Carr and B. A. Whitton. Oxford: Blackwells Scientific Publications.

Whitton, B. A., CARR, N. G. \& Craig, I. W. (1971). A comparison of the fine structure and nucleic acid biochemistry of chloroplasts and blue-green algae. Protoplasma 72, 325-357. 